REVIEW ARTICLE

\title{
INTRINSIC AND EXTRINSIC FACTORS IN THE CONSERVATION OF ANTS AND THEIR USE AS BIOINDICATORS
}

\author{
M.L. Bution', M.F. de A. Tango ${ }^{3}$, F.H. Caetano ${ }^{2}$
}

${ }^{1}$ Universidade Estadual de Campinas, Instituto de Biologia, Departamento de Genética, Evolução e Bioagentes, CP 6109, CEP 13083-970, Campinas, SP, Brasil. E-mail: mlbution@yahoo.com.br

\begin{abstract}
Ant communities are sensitive to fragmentation responding through: extinction of specialist species compared with large habitats, invasion of generalist species, changes in community composition and richness of species. Because of these characteristics, this review aims at examining the main risks that ants have been facing to maintain their communities, as well as to report current conservation practices in Brazil and in the world.
\end{abstract}

KEY WORDS: Ants, fragmented landscapes, environmental biomonitoring, matrix quality.

\section{RESUMO}

FATORES INTRÍNSECOS E EXTRÍNSECOS NA CONSERVAÇÃO DE FORMIGAS E SEU USO COMO BIOINDICADORES. Comunidades de formigas são sensíveis à fragmentação e respondem por meio: da extinção de espécies especialistas comparadas com grandes habitats, invasão de espécies generalistas, mudanças na composição da comunidade ena riqueza de espécies. Por causa dessas características, esta revisão pretende descrever os principais riscos que as formigas têm enfrentado para manter suas comunidades, como também descrever práticas atuais no Brasil e no mundo.

PALAVRAS-CHAVE: Formigas, paisagens fragmentadas, biomonitoramento ambiental, qualidade da matriz.

\section{INTRODUCTION}

Habitat fragmentation affects the ecosystem in several ways by causing important disturbances to species as they interact with their environment, such as in pollination (AIZEN; FEINSINGER, 1994), predation of nests and seeds (Kareiva, 1987; Oehler; Livaitis, 1996; Wong et al., 1998) or changes in community composition (BRUHL et al., 2003).

Despite the dominance of arthropods in Neotropical forests, most studies on theimpact caused by habitat fragmentation focus on vertebrates. Insects may be especially affected by the fragmentation process, as they are more susceptible to environmental disturbances and usually have low dispersal ability (DidHAm et al., 1996). In addition, the effects of ecosystem fragmentation and the genetic composition of populations can be more readily evaluated, as the generation time is shorter (BICKEL et al., 2006).

Ants are a key group in tropical ecosystems due to their role and biomass (Holldobler; WilsON, 1990;
JONES et al., 1994). Ant communities are sensitive to fragmentation responding through: extinction of specialist species compared with large habitats (Boswell et al., 1998), invasion of generalist species (SuArez et al., 1998), and changes in community composition and richness of species (BESTELMEYER; Wiens, 1996; Carvalho; Vasconcelos, 1999; Majer; DELABIE, 1999; BRUHL et al., 2003). Studies conducted by BICKEL et al. (2006) have shown a significant decline in species diversity, in addition to changes in composition and reduction of ant density in tropical areas, as observed in Sabah, Borneo (Malaysia).

Another important factor is the threat of extinction that many ant species are facing. The red list of endangered species (IUCN 2000) comprises 151 seriously endangered ant species (HILTON-TAYLOR, 2000; CHAPMAN; BOURKe, 2001).

Because of these characteristics, this review aims at examining the main risks that ants have been facing to maintain theircommunities, as wellas toreportcurrent conservation practices in Brazil and in the World.

\footnotetext{
${ }^{1}$ Universidade Estadual Paulista, Instituto de Biociências, Departamento de Biologia, Rio Claro, SP, Brasil.

${ }^{3}$ Centro Universitário Barão de Mauá, Ribeirão Preto, SP, Brasil.
} 


\section{Threats to ants}

IUCN (2000) listed 151 social insects as endangered species (Hilton-Taylor, 2000; Chapman; Bouke, 2001), all ants. Among these, three ant species are listed as critically endangered, basically due to endemism. For instance, Adetomyrma venatrix is described based on only one collection from the Zombitse Forest in Madagascar (WARD, 1994). Aneuretus simoni is restrict to two small fragments in Sri Lanka (BoLTON, 2001), and Nothomyrmecia macropsis known in two localities, one in western and another in southern Australia (TAYLOR, 1978).

Six of these ant species are listed as low risk and all are "wood ants" of the genus Formica. The remaining 142 ant species are considered vulnerable, subcategory D2, which are characterized as populations in restrict areas or in less than five localities (HILTON-TAYLOR, 2000; CHAPMAN; BOURKE, 2001).

\section{Influence of habitat fragmentation on the viability of ant populations}

Studies conducted by BicKeletal. (2006) on two ant species considered specialists, Odontomachus rixosus (Ponerinae) and Pheidole annexus (Myrmicinae), aimed at examining the impact of habitat fragmentation on the genetic diversity and population structure using genetic markers (RAPD- fingerprinting).

Ants weresampled in a contiguous area (43.000ha) of primary tropical forest in Sabah, Borneo (Malaysia), and in three patches of forest of different sizes $(4,294$, 146, and 20 ha, respectively) that were fragmented approximately 40 years ago. The authors observed a decrease in genetic variability in both species in the populations of all fragmented areascompared withant populations of the contiguous area.

The reduction of genetic diversity was observed through several methods used to assess genetic variability (nucleotide diversity, heterozygosity, and proportion of polymorphic loci).

Nucleotide diversity was relatively low for both species (BICKEL et al., 2006). The decrease in heterozygosity in fragmented forests of both species may be an effect of inbreeding and genetic drift, which areexpected in small population such as those studied by these authors.

The increase in inbreeding in fragmented populations is associated to the loss in the capacity to adapt to environmental changes that any living being is subjected (TEMPLETON; READ, 1994). In addition to limited evolutionary flexibility, inbreeding in Formicidae may lead to a serious inbreeding depression, producing diploid males in detriment to haploid males. The latter are viable to the haplodiploid sex-determination system in ants (BICKEL et al., 2006), while diploid males are usually sterile and have a cost to the colony (GIRAUD et al., 2000).

The genetic variation found in these populations may be due to the isolation caused by the distance among fragments. BICKEL et al. (2006) also observed a high level of population subdivision, suggesting a lack of meta-population dynamics due to a shortage of gene flow among populations, possibly a result of the high degree of habitat isolation, in addition to a low dispersal efficiency in long distances. In this study, the authors concluded that relatively large (approximately $4000 \mathrm{ha}$ ) protected but very isolated areas may not be enough to maintain the original genetic diversity of ant populations. Thus, this may not prevent genetic erosion or the consequences associated with theloss in genetic variability, including a high susceptibility to extinction.

\section{Genetic conservation of ants in fragmented landscapes}

GYLLENSTRAND;SEPPA (2003) studied a small isolated and fragmented population of ants (Formica lugubris) in England, where the impact of the social and genetic structure on the persistence of the population was examined. Gene flow was assessed using nuclear (microsatelites DNA) and mitochondrial markers, which can separate gene flow by the two sexes.

Several intrinsic factors combined to characteristics of sociality influence the persistence of populations of social insects, including the low effective population size that reduces the amount of genetic variation, which in turn may lead to inbreeding depression (GYLLENSTRAND; SEPPA, 2003).

In these studies, the effective population size was large, as all nests were polygynous. Despite the apparent isolation, the large genetic variability was similar to that of non-isolated populations, indicating that this population is not undergoing inbreeding depression due to intense male gene flow (GYllenstrand; SEPPA, 2003). Thus, the persistence of the population is not being threatened by genetic or social factors. However, these authors predict that colonization of new habitats may be difficult due to the restrict dispersion of queens.

The effective population size may be small even when the biomass is abundant; social insect populations can be spatially structured and haplodiploidy reduces genetic variation and can easily lead to inbreeding depression (PAMILO; CROZIER, 1997; ChAPMAN; BOURKE, 2001; GYLLENSTRAND; SEPPA, 2003).

The effective population size depends on the number of nests as well as the level of polygyny (i.e. number of reproductivequeenspernest).Inspecieswithmonogynous colonies, theeffectivepopulationsizematchesthenumber of nests. On the other hand, in polygynous nests, the 
effectivepopulationsizeis potentially manifold compared to the number of nests when coexisting queens share the reproductive role in the colony (PAMILO; GROZIER, 1997; GYLLENSTRAND; SEPPA, 2003).

In social hymenopterans, haplodiploidy can also contribute to reduce the effective population size, as in the case diploid males (CROZIER, 1979; PAMILO; CROZIER, 1997; CHAPMAN; BOURKE, 2001). The effect of these factors areclearly seen in populations of Eciton burchelli, in Barro Colorado Island, Panama, with approximately 50 colonies in 1500 ha of the island, each having only one queen surrounded by 400000 sterile workers (FRANKS, $1982,1985)$. This, in addition to forest fragmentation in the island, makes this ant species vulnerable to the threats in its habitats (BoswELL et al., 1998).

As a consequence of haplodiploidy in hymenopterans, there was less genetic variation (decrease in heterozygosity) compared to otherinsects (Hedrick; Parker, 1997; Gyllenstrand; Seppa, 2003). Oneimportantconsequenceof reduced heterozygosity is inbreeding depression that results from the production of diploid males. Individualshomozygous at the sexual locus are diploid males, which are sterile and do not benefit the colony (COOK; CROZIER, 1995). The frequency of diploid male production depends on the number of sex alleles in the population, which is directly correlated with the size and isolation of the population (GYLLENSTRAND; SEPPA, 2003).

Dispersal of individuals and the spatial structure of populations are important determinants of the survival of a species, especially in fragmented landscapes (Holldobler; Wilson, 1990).

GYLLENSTRAND;SEPPA (2003) expected a decrease in variability in large and fragmented populations of English ants compared with fragmented but not isolated populations. However, the unexpected large effective population size maintained the variability in this population.

The difference in genetic structure revealed by biparental (nuclear) and uniparental (mitochondrial) markers was remarkable. Because of the large difference between estimates of both markers, male gene flow was probably higher than female gene flow (GYllenstrand; SePpa, 2003). Thus, these authors showed that dispersal and gene flow in polygynous F. lugubris queens can be strongly restricted. This may have serious consequences for the persistence of the population as it weakens the colonization ability of new fragmented habitats. This applies not only to the founding of new subpopulations, but also for the recolonization of current areas, should they become extinct for some reason.

Environmental characteristics and their implications for the conservation of ant communities in the Brazilian Pantanal
Covering an area of $140.000 \mathrm{~km}^{2}$, the Brazilian Pantanal is one of the World's largest freshwater wetland areas, consisted of a seasonally flooded plain. The annual and pluriannual cycles of floods of several rivers of Pantanal are the most important ecological phenomenon in the region. Floods are not correlated with the intensity of local rainfalls, but to difficulties in drainage due to the low declination in topography (CAlHeiros et al., 2000; Ribas; Schoereder, 2006).

In this biome, gallery forests arecritical components of the floodplain landscape, as they function as dry refuges or land corridors for animals during floods. They are roosting and nesting sites for water birds, sources of food for fishes, in addition to comprising a unique combination of trees capable of tolerating seasonal flooding (HAMiLTON, 2002).

In ant communities, heterozygosity and resource availability, as described above, have been considered important processes to maintain species richness (Ribas et al., 2003; ARMBreCHT et al., 2005). These processes are widely used as biological indicators of habitat conservation status, in addition to being good disturbance indicators (ANDERSEN et al., 2002; RIBAS; SCHOEREDER, 2006).

RIBAS; SCHOEREDER (2006) examined the use of ants to predict human impacts on the Pantanal, evaluating how environmental characteristics of gallery forests influence richness of arboreal ants. To this end, these authors tested how resource availability (estimated by tree density) and diversity of environmental conditions (estimated by structural heterogeneity) positively influenced the richness and composition of ant species. In this study, these authors showed that species richness was not affected by tree density, although RiBAs et al., (2003) obtained a significant positive relationship between richness of arboreal ants and tree density in the Brazilian savanna (Cerrado). These conflicting results suggest that ant richness in the Brazilian Pantanal is determined by a different mechanism. On the other hand, species composition was significantly affected by tree density, indicating the importance to preserve heterogeneous environmental conditions (RIBAS; SCHOEREDER, 2006).

The negative impact on the richness and composition of the fauna of arboreal ants caused by the decrease in diversity of the environmental conditions may negatively affect pollination (GOMEZ, 2000), seed dispersal (GILADI, 2006), and nutrient recycling (Dostal et al., 2005), causing a major impact on the plant composition of gallery forests. Thus, RIBAS AND SCHOEREDER (2006) concluded that ants may be used as important tools to predict human impact on the Pantanal and that the degradation of gallery forests has negative impacts on this fauna.

\section{Response of ants to forest fragmentation}


Several studies have recently focused on the use of ants as bioindicators of the conditions of degradation or recovery of terrestrial ecosystems in studies of biodiversity conservation. This is partially due to the fact that ants are easily sampled, relatively easily identifiable at a species level, and usually sensitive to environmental changes (VASCONCELOS, 1998).

Ants play a very important ecological role in tropical and subtropical ecosystems. They are one of the dominant groups in number of species as well as biomass. In forests near Manaus, the biomass of ants is estimated to be four times that of the all vertebrates combined (FITTIKAU; KLINGE, 1973; VASCONCELOS, 1998).

Ants affect soil structure and fertility, and usually have a major impact on other components of fauna and flora, as they prey on seeds and other arthropods, in addition to cutting leaves and functioning as decomposers (Holldobler; Wilson, 1990).

VASCONCELOS (1998) conducted a study on the biological dynamics of forest fragments near Manaus with ground-foraging ants. In a first assessment, the author evaluated the response of ants to different levels of human disturbance in the region. The structure of ground-foraging ant communities was compared in four habitats representing a disturbance gradient associated with differences in land use.

Samplings were carried out in undisturbed mature forest and in three areas previously cleared 11-13 years ago. Two areas were used as pastures (used for 10 and 2 years) before being abandoned, whilea third one was not used as pasture, and was abandoned soon after clearing.

The degree of habitat disturbance significantly affected all variables measured: ant abundance, and species richness and composition (VASCONCELOS,1998). Thehighest levels of disturbance resulted in a decrease in species richness and increase in ant abundance.

Both pasture and young regrowth forest (in a former pasture area) exhibited a distinct species composition compared with that found in the mature forest. Species composition in the old regrowth forest (in area not used as pasture) was similar to that of the mature forest (VASCONCELOS, 1998).

In a second assessment, the author analyzed the response of ants to the decrease in forest area as a consequence of the deforestation previously described. Ants were collected in forest fragments varying between 1 and 100 ha, and in a contiguous forest. In each of these areas (a total of 9), 1 ha was defined as a sampling lot. Between 78 and 111 ant species were found in each 1-ha lot, and between 106 and 151 were estimated to be potentially found in these areas.

VASCONCELOS (1998) did not find a significant relationship between forest fragment size and number of ant species per ha (species density). However, species composition varied significantly with fragment size and location. The effect of location suggests that different geographic regions in Central Amazon exhibit differences in species composition despite relatively short distances $(10-25 \mathrm{~km})$.

Thus, given the heterogeneity in spatial distribution of ant species in the forest, having protected areas in different geographic regions and not only in one or few regions is preferable.

Later analyses suggest that changes in ant species composition and forest fragment size are in fact a result of border effect, which affects proportionally more small fragments than large ones. Near the border of fragments, trees are smaller and the leaf litter is more abundant, which are factors that apparently cause changes in the composition of ant species and maybe other invertebrates in the forest (VASCONCELOS, 1998).

The use of ants in environmental biomonitoring to qualitatively evaluate disturbed areas

According to Hilty; Merenlender (2000), biomonitoring programs are based on measurements of species richness and on the trophic structure of the environment. Some species are sensitive to changes in their environment and among them, ants can be efficient bioindicators especially due to their abundance, diversity, ecological importance at all trophic levels, easiness of sampling, and sensitivity to environmental changes MAJER, 1983; GreEnSLADE; Greenslade, 1984). Playing an important role in soil formation, ants arealso affected by changes in patterns of plant succession, making their importance even more evident in recovering habitats (FOWLER, 1998).

Focusing on these peculiarities, RÉ; SLVA (2007) conducted studies with ants aiming at defining a biomonitoring system to evaluate the efficiency and progression of reforestation techniques adopted by a company mining heavy minerals in the northernmost areas of Paraíba State, Millennium Chemicals do Brasil S.A. This monitoring had the purpose of positively contributing to the decision making for the improvement of theenvironmentalmanagementadopted.Inthisstudy, theauthorsdefined5samplingsites based on thefollowing parameters: reforestation time, substrate treatment, type of planting, annual size of reforested areas, arrangement and shape of areas and a control area representative of the original habitat prior to the planting process.

The vegetation in the rehabilitated areas was planted in 1989; 1992; 1995; and 2000. The area planted in 1989 was the oldest and the first to be rehabilitated; and the areas planted in 1992 and 1995 were in intermediary regrowth stages.

Using pitfall traps, RÉ; SILVA (2007) obtained a larger diversity of ants and specialist ants in more preserved areas (older) and lower diversity and generalist species in more disturbed areas (younger), which was somewhat expected. In this study, it is 
clear that the use of simple and low-cost techniques can produce results in a short period of time, allowing the compilation of comprehensive environmental inventories. When applied to long periods of time, preferably since the beginning of the planning phase, they can provide valuable information on the extent of the human impact, aiding in the decision-making.

Matrix quality in a tropical fragmented landscape and its influences on ant communities

In theory, a matrix can affect the migration rates of organisms among forest fragments and thus influence extinction rates at a regional level. A matrix may also create conditions that alter extinction rates among fragments (GuSTAFSON; GARDNER, 1996; CANTRELl et al., 1998).

The efforts on the conservation of fragmented landscapes frequently focus on the characteristics of fragmented habitats. However, PERfECTO; $V$ ANDERMEER (2001) proposed that the matrix in which the fragment occurs is of equal importance and quality should be taken into account as an important variable.

The authors used ant species richness as an index to evaluate matrix quality in montaneforest fragments, where the matrix consisted of coffee plantations in southwestern Chiapas, Mexico. Ants were sampled in plots at various distances $(2$ to $750 \mathrm{~m}$ ) from a fragment on two farms. One farm used organic techniques with considerable shade due to the agroecosystem adopted, while the other used conventional methods with spotty shade. Ant species richness was not significantly different between the forest fragment and the matrix using organic techniques, but it was significantly different between the forest fragment and the matrix using conventional methods. However, species richness decreased with distance from the forest fragment in matrix types (Perfecto; Vandermeer, 2001). The decrease in ant species richness was higher in the conventional farm (low-quality matrix) than in organic farm (high-quality matrix), suggesting that matrix quality is important for the conservation of ant diversity.

The context of these results may be correlated with ecological corridors among fragmented habitats, in which the basic dynamics are similar in the effort to lower extinction rates in fragmented landscapes (Brown; Kodric-Brown, 1977; HansKI, 1985, 1991), or repopulatefragments that for somereasonexperienced an extinction event (LEVINS, 1969).

The basic difference between a corridor and a matrix is that the former consists of a passage between two fragments through an extremely hostile matrix if matrix quality is permeable to promote the passage between two fragments, and provide temporary shelter for dispersing animals. The matrix may provide an alternative strategy to connect two fragments, similarly to ecological corridors.

\section{Threat of invasive species to native populations}

One of the mechanisms through which modern extinctions occur was identified by DIAMOND (1984). He suggested that the extinction of native species may occur due to the effects caused by introduced species, which are extremely invasive, representing a threat to social as well as solitary insects, other arthropods, plants and vertebrates (MOLLER, 1996; SuAREz et al., 1998; ChAPMAN; BOURKe, 2001).

Once established in a new territory, introduced social insects may rapidly expand due to their ability to dominate resources with high numbers of individuals (WILSON, 1990, 1992), in addition to high dispersion ability, fast reproduction, and efficient defenses against predators. They also may benefit from a behavioral and ecological flexibility allowed by sociality (MOLLER, 1996).

The group of invasive specialist species listed by IUCN was the base for the development of the Global InvasiveSpecies Database and Early Warning System (GISP 2001). This lists comprises the 100 most invasive species, among which four are ants: Anoplolepis gracilipes, Linepithema humile, Pheidole megacephala, and Solenopsis invicta.

Poter; Savignano (1990) described S. invicta as responsible for the loss of $70 \%$ of ant species richness in Texas, due to factors associated to intraspecific competition. This loss resulted in a 30\% decrease in arthropod richness, affecting birds (MUELLER et al., 1999) and mammals (Allen etal., 1997). In California, the presence of the Argentinean ant L. humile caused severe decrease and sometimes disappearance of native species (HumAN; GORDON, 1996; SuAREz et al., 1998). In Hawaii, L. humile is a serious threat to endemic arthropods (CoLE et al., 1992).

Theaboveresults show theimportancethat studies on environmental impacts and the pre-establishment of any type of human activity have on the knowledge and maintenance of ant communities. This also raises the question on monitoring the recovery quality in areas disturbed by human activities using ants as an excellent tool, due to the easiness of execution, low cost or the small amount of time spent of this type of study. However, myrmecologists skilled in the identification of collected species are essential in the study team.

\section{ACKNOWLEDGMENTS}

The authors thank the Silvia Galleti and anonymous referees for their suggestions and criticism 
that greatly improved the quality of this manuscript. Murillo Lino Bution tanks to Conselho Nacional de Desenvolvimento Científico e Tecnológico (CNPq proc.142211/2006-0) and to Profa. Dra. Maria José de Oliveira Campos.

\section{REFERENCES}

AIZEN, M.A.; FEINSINGER, P. Forest fragmentation, pollination and plant reproduction in a Chaco dry forest, Argentina. Ecology, v.75, p.330-351,1994.

ALLEN, C.R.; DEMARAIS, S.; LUTZ, R.S. Effects of red imported fire ants on recruitment of white-tailed deer fawns. Journal of Wildlife Management, v.61, p.911-916, 1997.

ANDERSEN, A.N.; HOFFMAN, B.D; MULHER, W.J; GRIFFITS, A.D. Using ants as bioindicators in land management; simplifying assessment of ant community responses. Journal of Applied Ecology, v.39, p.8-17, 2002.

ARMBRECHT, I; RIVERA, L.; PERFECTO, I. Reducer diversity and complexy in the leaf-litter ant assemblages of Colombian coffee plantations. Conservation Biology, v.19, p.897-907, 2005.

BESTELMEYER, B.T.; WIENS, J.A. The effects of land use on the structure of ground-foraging ant communities in the Argentine Chaco. Ecological Applications, v.6, p.1225-1240, 1996.

BICKEL- TOBIAS, O.; CARSTEN, A.; BRUHL; GADAU, J.R; BERT HOLLDOBLER; and K. EDUARD LINSENMAIR. Influence of habitat fragmentation on the genetic variability in leaf litter ant populations in tropical rainforests Sabah, Borneo. Biological Conservation, v.15, p.157-175, 2006.

BOLTON, B. Identification guide of the ant genera of the world. Cambridge: Harvard University Press, 2004. 732p.

BOSWELL, G.P.; BRITTON, F.N.; FRANKS, N.R. Habitat fragmentation, percolation theory and the conservation of a keystone species. Proceedings of the Royal Society of London. Series B: Biological Sciences, v.265, p1921-1925, 1998.

BROWN, J.H.; KODRIC-BROWN, A. Turnover rates in insular biogeography. Ecology, v.58, p.445-449, 1977.

BRUHL, C.A.; ELTZ, T.; LINSENMAIR, K.E. Size does matter - effects of tropical rainforest fragmentation on the leaf litter ant community in Sabah, Malaysia. Biological Conservation, v.12, p.1371-1389, 2003.

CALHEIROS, D.F.; SEIDL, A.F.; FERREIRA, C.J.A. Participatory research methods in environmental science: local and scientific knowledge of a limnogical phenomenon in the Pantanal Wetland of Brazil. Journal of Applied Ecology, v.37, p.684-696, 2000.

CANTRELL, R. S.; COSNER, C.; FAGAN, W. F. Competitive reversals inside ecological reserves: the role of external habitat degradation. Journal of the Mathematical Biology, v.37, p.491-533. 1998.

CARVALHO, K.S.; VASCONSELOS, H.L. Forest fragmentation in central Amazonia and its effects on litter-dwelling ants. Biological Conservation, v.91, p.151157, 1999.

CHAPMAN, R.E; BOURKE, A.F.G. The influence of sociality on the conservation biology of social insects. Ecology Letters, v.4, p.650-662, 2001.

COLE, F.R.; MEDEIROS, A.C.; LOOPE, L.L.; ZUEHLKE, W.W. Effects of argentine ant on arthropod fauna of Hawaiian high-elevation shrubland. Ecology, v.73, p.1313-1322, 1992.

COOK, J.M.; CROZIER, R. H. Sex determination and population biology in the hymenoptera. Trends in Ecology \& Evolution, v.10, p.281-286, 1995.

CROZIER, R.H. Genetics of sociality. In: HERMANN H.R. (Ed.). Social insects. New York: Academic press, 1979. v.1, p.223-286.

DIAMOND, J.M. 'Normal' extinctions of isolates populations. In: NITECKI, M.H. (Ed.). Extinctions. Chicago: University of Chicago Press, 1984. p.191-246.

DIDHAM, R.K.; GHAZOUL, J.; STORK, N.E.; DAVIS, A.J. Insects in fragmented forests: a functional approach. Trends in Ecology \& Evolution, v.11, p.255-261, 1996.

DOSTAL, P.; BREZNOVA, M.; KOZLICKOVA, V.; HERBEN, T.; KOVAR, P. Ant-induced soil modification and its effect on plant below-ground biomass. Pedobiologia, v.49, p.127-137, 2005.

FITTKAU, F.J; KLINGE, H. On biomass and trophic structure of the central Amazonian rain forest ecosystem. Biotropica, v.5, p.2-14, 1973.

FOWLER, H.G. Provas de melhoria ambiental. Ciência Hoje, v.24, p.69-71, 1998.

FRANKS, N. Ecology and population regulation in the army ant Eciton burchelli. In: LEIGH, E.G., RAND, A.S.; WINDSOR, D.W. (Ed.). The ecology of a tropical forest. Washington DC: Smithsonian Institute Press, 1982. p.389-395.

FRANKS, N.R. Reproduction, foraging efficiency and worker polymorphism in army ants. In: HOLLDOBLER, B.; LINDAUER, M. Experimental 
behavioral ecology and sociobiology. Stuttgart: Gustav Fischer, 1985. p.91-107.

GILADI, I. Choosing benefits or partners: a review of the evidence for the evolution of myrmecochory. Oikos, v.112, p.481-492, 2006.

GIRAUD, T.; BLATRIX, R.; POTEAUX, C.; SOLIGNAC, M.; JAISSON, P. Population structure and mating biology of the polygynous ponerine ant Gnamptogenys striatula in Brazil. Molecular Ecology, v.9, p.1835-1841, 2000.

GROUP INVASIVE SPECIES SPECIALIS. 2001: Global Invasive Species Database and Early Warning System. WWW document, URL http://www.issg.org/ database.

GOMEZ, J.M. Effectiveness of ants as pollinators of Lobularia maritima: effects on main sequencial fitness components of the host plant. Oecologia, v.122, p.90-97, 2000.

GREENSLADE P.J.M; GREENSLADE, P. Invertebrates and environmental assessment. Environmental and Planning, 3, p.13-15, 1984.

GUSTAFSON, R.J.; GARDNER, R.H. The effect of the landscape heterogeneity on the probability of patch colonization. Ecology, v.77, p.94-107, 1996.

GYLLENSTRAND, N.; SEPPA, P. Conservation genetics of the wood ant, Formica lugubris, in a fragmented landscape. Molecular Ecology, v.12, p.2931-2940, 2003.

HAMILTON, S.K. Human impacts on hydrology in the Pantanal wetland of South America. Water Science and Technology, v.45, p.35-44, 2002.

HEDRICK, P.W; PARKER, J.D. Evolutionary genetics and genetic variation of haploids and X-linked gees. Annual Review of Ecology and Systematics, v.28, p.55-83, 1997.

HILTON-TAYLOR, C. (compiler) IUCN Red List of Threatened Species. Gland, Switzerland: IUCN.2000.

HILTY J.; MERENLENDER, A. Faunal indicator taxa selection for monitoring ecosystem health. Biological Conservation, v.92, p.185-197, 2000.

HOLLDOBLER, B.; WILSON, E. O. The ants. Cambridge: Belknap Press of Cambridge University, 1990. 713p.

HUMAN, K.G.; GORDON, D.M. Exploitation and interference competition between the invasive Argentine ant, Linepithema humile, and native ant species. Oecologia, 105, p.405-412, 1996.

JONES, C.G.; LAWTON, J.H.; SHACHAK, M. Organisms as ecosystem engineers. Oikos, v.69, p. 373386, 1994.

KAREIVA, P. Habitat fragmentation and the stabillity of predator-prey interactions. Nature, v.26, p.388-390, 1987.
LEVINS, R. Some demographic and genetic consequences of environmental heterogeneity for biological control. Bulletin of the Entomological Society of America, v.15, p.237-240, 1969.

MAJER, J.D. Ants: Bio indicators of minesite rehabilitation, land-use, and land conservation. Environmental Management, v.7, p.375-383, 1983.

MAJER, J.D.; DELABIE, J.H.C. Impact of tree isolation on arboreal and ground ant communities in cleared pasture in the Atlantic rain forest region of Bahia, Brazil. Insectes Sociaux, v.46, p.281-290, 1999.

MOLLER, H. Lessons for invasion theory from social insects. Biological Conservation, v.78, p.125-142, 1996. MUELLER, J.M.; DABBERT, C.B.; DEMARAIS, S; FORBES, A. R. Northern bobwhite chick mortality caused by red imported fire ants. Journal of Wildlife Management, v.63, p.1291-1298, 1999.

OEHLER, J.D.; LIVAITIS, J.A. The role of spatial scale in understanding responses of medium sized carnivores to forest fragmentation. Canadian Journal of Zoology, v.74, p.2070-2079, 1996.

PAMILO, P., CROZIER, R.H. Population biology of social insect conservation. Memoirs of the Museum of Victoria, 56, p.411-419, 1997.

PERFECTO, I.; VANDERMEER. Qulaity of agroecological matrix in a tropical montane landscape: ants in coffee plantations in southern México. Conservation Biology, v.16, p.174-182, 2002.

PORTER, S.D.; SAVIGNANO, D.A. Inviation of polygyne fire ants ecimates native ants and disrupts arthropod community. Ecology, v.71, p.2095-2106, 1990.

RÉ, T.M.; SILVA, C.S. da O uso de formigas no biomonitoramento ambiental: uma proposta metodológica para a avaliação qualitativa de dunas litorâneas reabilitadas. Mataraca - PA. Millennium Chemicals do Brasil S.A. 5p. Disponível em: <http:/ / www.cemac-ufla.com.br/trabalhospdf/trabalhos $\% 20$ voluntarios/protoc\%20129.pdf>. Acesso em: 21 jul. 2007.

RIBAS, C.R; SCHOEREDER, J.H.; PIC, M.; SOARES, S.M. Tree heterogeneity, resource availability, and larger scale process regulating ant species richness. Austral Ecology, v.28, p.305-314, 2003.

RIBAS, C. R; SCHOEREDER, J. H. Ant communities, environmental characteristics and their implications for conservation in the Brazilian Pantanal. Biodiversity Conservation, [DOI 10.1007/s10531-006-9041-x.2006].

SUAREZ, A.V.; BOLGER, D.T.; CASE, T.J. Effects of fragmentation and invasion on native ant communities in coastal southern California. Ecology, v.79, p.2041-2056, 1998. 
TAYLOR, R. W. Nothomyrmecia macrops: a living-fossil ant recovered. Science, v.201, p.979-985, 1978.

TEMPLETON, A.R.; READ, B. “Inbreeding: one wordseveral meanings, much confusion" In: LOESCHCHE, V.; TOMIUK, J.; JAIN, S.K. (Ed.). Conservation genetics. Berlin: Birkhäuser Verlag, 1994. p.91-105.

VASCONCELOS, H. L. Respostas das formigas à fragmentação florestal. Série técnica IPEF, v.12, p.95-98, 1998.

WARD, P.S. Adetomyrma, na enigmatic new ant genus from Madagascar (Hymenoptera, Formicidae), and its implications for ant phylogeny. Systematic Entomology, v.19, p.159-175, 1994.
WILSON, E.O. Success and dominance in ecosystems: the case of the social insects. Oldendorf: Ecology Institute, 1990.

WILSON, E. O. The effects of complex social life on evolution and biodiversity. Oikos, v.63, p.13-18, 1992. WONG, T.C.M.; SODHI, N.S.; TURNER, I.M. Artificial nest and seed predation experiments in tropical lowland rainforest remnants of Singapore. Biological Conservation, v.85, p.97-104, 1998.

Received on $13 / 10 / 08$

Accepted on 25/10/09 